\title{
Habituation of Neurosecretory Responses to Extracellular ATP in PC12 Cells
}

\author{
Laura Cheever ${ }^{\mathrm{a}}$ and Daniel E. Koshland, Jr. \\ Department of Molecular and Cell Biology, Division of Biochemistry and Molecular Biology, University of California at \\ Berkeley, Berkeley, California 94720
}

\begin{abstract}
Neuronally differentiated PC12 cells have been used as a model for habituation. These cells secrete norepinephrine in response to extracellular ATP, as well as other stimulants, and the response is diminished with repetitive stimulation. This loss of neurosecretory responsiveness displays characteristics commonly associated with habituative learning. These include an increase in both the rate and the relative degree of response loss with either increasing stimulation frequency or decreasing stimulus intensity, and selective generalization of the decreased responsiveness to heterologous stimuli. In PC12 cells, the loss of neurosecretory responsiveness appears to be entirely caused by stimulation-dependent inactivation of the ATP-gated cation channel. Several unusual properties of this channel apparently allow its regulation to produce the behaviors associated with short-term habituation. Recovery of the ATP-gated channel requires several minutes, allowing habituation of responses to repetitive stimuli given at intervals of several minutes. Inactivation of the ATP-gated channel may be proportionately faster in response to lower ligand concentrations, allowing habituation to be more rapid in response to stimuli of weaker intensity.
\end{abstract}

[Key words: receptor-operated channel, purinergic receptor, desensitization, inactivation, adaptation]

Habituation is the process by which an organism learns to diminish its response to a stimulus with repetition of that stimulus. Habituation is nearly ubiquitous (Harris, 1943), having been described in a wide variety of organisms including, but not limited to, protozoa (Wood, 1988), mollusks (cf. Pinsker et al., 1970), insects (cf. Corfas and Dudai, 1989), amphibians (cf. Farel et al., 1973), and mammals (cf. Thompson and Glanzman, 1976). A number of characteristic behaviors are common to habituative learning in a variety of behavioral studies (Thompson and Spencer, 1966). These include an exponential decrease in the response to a stimulus as that stimulus is repeated and spontaneous recovery of the response when the stimulus is withheld. Following habituation and rccovery of a response, the rate of habituation to a second series of repetitive stimuli is often increased, indicating a memory of prior habituation that may

\footnotetext{
Received Sept. 8, 1993; revised Jan. 26, 1994; accepted Feb. 8, 1994.

We thank Ann Fischer for her expert cell culturing. This work was supported by Grant DK09765 from the National Institutes of Health.

Correspondence should be addressed to Daniel E. Koshland, Jr., at the above address.

"Present address: Howard Hughes Medical Institute, University of California at San Francisco, Third and Parnassus Avenue, Room U-426, San Francisco, CA 94143-0724.

Copyright $\odot 1994$ Society for Neuroscience $0270-6474 / 94 / 144831-08 \$ 05.00 / 0$
}

endure long after the response has recovered (Peeke and Petrinovich, 1984). Both the rate and relative extent of response loss are typically increased with either increasing stimulation frequency or decreasing stimulus intensity. And, in some cases, the habituation of the response to one stimulus may be generalized to cause decreased responsiveness to heterologous stimuli. In several systems (cf. Castellucci et al., 1970; Kupfermann et al., 1970; Farel et al., 1973), habituation of behavioral responses is correlated with decreased activity of neurons lying within the pathway that mediates the behavioral response. In some cases, it has been shown that reduction of neurotransmitter release from the presynaptic cell is responsible for the decreased neuronal activity (Zucker, 1971; Castellucci and Kandel, 1974; Klein et al., 1980).

PC12 cells, rat pheochromocytoma cells that differentiate upon treatment with nerve growth factor to resemble closely sympathetic neurons (Greene and Tischler, 1976; Dichter et al., 1977) are frequently used to study mechanisms of neuronal signal transduction and neurotransmitter release. PC12 cells take up radiolabeled norepinephrine (NE) and store it in vesicles along with endogenous catecholamines (Greene and Rein, $1977 \mathrm{~b}$ ). The radiolabel is secreted in response to a variety of stimulants that elevate the cytosolic calcium concentration, including acetylcholine (Greene and Rein, 1977b) and depolarization (Greene and Rein, 1977a), permitting simple measurement of neurotransmitter release. Extracellular ATP has more recently been found to also stimulate norepinephrine release from PC12 cells (Inoue et al., 1989). ATP has long been proposed to act as a neurotransmitter (Holton and Holton, 1954) and evokes excitatory responses in both the CNS (Edwards et al., 1992) and PNS (cf. Yatani et al., 1982; Jahr and Jessel, 1983; Fyffe and Perl, 1984), including sympathetic neurons (cf. Siggins et al., 1977).

In a previous study, we found that ATP-evoked NE release from PC 12 cells is diminished with repetitive stimulation and displays several characteristics of both short- and long-term habituation (Cheever and Koshland, 1992). In particular, neurosecretory responsiveness decreases exponentially with repeated application of ATP and recovers spontaneously when stimulation is withheld. Following habituation and recovery of the response, habituation occurs more rapidly to a second series of repetitive stimuli. Similar modulation of neurotransmitter release occurring in neurons mediating a behavioral response would cause habituation of that response. Since the mechanisms underlying neurosecretory modulation are likely to be similar in vivo and in cultured cells, PC12 cells can provide a model system for investigating the molecular mechanisms underlying habituative processes (McFadden and Koshland, 1990a). Cell 
lines offer the advantage of being more amenable to biochemical analysis than more complex neural preparations. In this report, PC 12 cells stimulated with ATP are tested to determine whether they display the remaining characteristics associated with habituative learning, and the mechanisms of neurosecretory habituation are explored.

\section{Materials and Methods}

Cell culture. PCI 2 cells (American Tissue Culture Collection) were grown either on cytodex 3 beads (Sigma, St. Louis, MO) as previously described (McFadden and Koshland, 1990a) or in suspension. Cells were differentiated with $50 \mathrm{ng} / \mathrm{ml} \mathrm{NGF}$ (Harlan Bioproducts for Science, Indianapolis) in RPMI 1640 (Irvine Scientific, Santa Ana, CA) containing $5 \%$ fetal bovine serum (HyClone, Logan, UT), 10\% horse serum (JRH Biosciences, Lenexa, KS), supplemental glutamine, penicillin, and streptomycin for 6-7 d before use (Greene and Tischler, 1976).

${ }^{3} \mathrm{H}-\mathrm{NE}$ release. The time course of ${ }^{3} \mathrm{H}-\mathrm{NE}$ release from $\mathrm{PC} 12$ cells was determined exactly as previously described (Cheever and Koshland, 1992). ${ }^{3} \mathrm{H}-\mathrm{NE}$ released from perfused cells was measured every $0.1 \mathrm{~min}$, and release at each time point was expressed as a percentage of the total ${ }^{3} \mathrm{H}-\mathrm{NE}$ remaining in the cells at that time, in order to correct for the ongoing loss of radiolabel. To determine the rates and extent of habituation, the total amount of ${ }^{3} \mathrm{H}-\mathrm{NE}$ released during each stimulus was corrected for basal release as well as ongoing loss of radiolabel. Data were then fit by curves described in the text by nonlinear regression (KALEIDAgraph, Abelbeck Software).

For single measurements of ${ }^{3} \mathrm{H}-\mathrm{NE}$ release (see Figs. 3, 5, 6), cells grown and differentiated in suspension were washed with low $\mathrm{K}^{+}$buffer (125 mM NaCl, $4.8 \mathrm{~mm} \mathrm{KCl}, 1.3 \mathrm{~mm} \mathrm{CaCl}_{2}, 1.2 \mathrm{~mm} \mathrm{MgCl}_{2}, 1.2 \mathrm{~mm}$ $\mathrm{K}_{2} \mathrm{HPO}_{4}, 5.6 \mathrm{~mm}$ D-glucose, and $25 \mathrm{~mm}$ HEPES, pH 7.4) by gentle centrifugation and resuspension, and were then loaded with $1 \mu \mathrm{Ci} / \mathrm{ml}$ ${ }^{3} \mathrm{H}-\mathrm{NE}$ in low $\mathrm{K}$ for $1 \mathrm{hr}$ at $37^{\circ} \mathrm{C}$. Unincorporated ${ }^{3} \mathrm{H}-\mathrm{NE}$ was removed by extensive washing and cells were resuspended in low $\mathrm{K}$. Fifty $\mathrm{mi}$ croliters of stimulant were added to $50 \mu \mathrm{l}$ aliquots of cells and incubated at $25^{\circ} \mathrm{C}$ for the indicated stimulation times. Cells were removed by centrifugation and the amount of ${ }^{3} \mathrm{H}-\mathrm{NE}$ released was determined by scintillation counting of an aliquot of the supernatant. The cells were then lysed with $1 \%$ Triton X-100 in order to determine the total amount of ${ }^{3} \mathrm{H}-\mathrm{NE}$ that had been present; released ${ }^{3} \mathrm{II}-\mathrm{NL}$ is expressed as a pcrcentage of the total taken up by the cells. For each measurement of stimulated NE release, ${ }^{3} \mathrm{H}-\mathrm{NE}$ in the supernatant of unstimulated cells treated in parallel was subtracted.

Intracellular calcium levels. Suspension cultures of differentiated $\mathrm{PC} 12$ cells were loaded with fura-2 by incubation for $1 \mathrm{hr}$ at $37^{\circ} \mathrm{C}$ with $1 \mu \mathrm{M}$ fura-2-AM (Molecular Probes, Portland, OR) in $10 \mathrm{ml}$ of low $\mathrm{K}^{+}$buffer. Free fura-2-AM was washed away, and cells were resuspended in $2 \mathrm{ml}$ low $\mathrm{K}^{+}$buffer. During calcium measurements, cells were maintained at $25^{\circ} \mathrm{C}$ with constant gentle stirring in the chamber of an SLM $4800 \mathrm{~S}$ fluorimeter. For each time point, the fluorescence intensity of the dye emitting at $510 \mathrm{~nm}$ was determined at excitation wavelengths of 340 and $380 \mathrm{~nm}$ in rapid succession. Three minutes after a stable basal recording was established, ATP in $0.5 \mathrm{ml}$ low $\mathrm{K}^{+}$was added. Where indicated, calcium-free low $\mathrm{K}^{+}$containing $0.1 \mathrm{~mm}$ EGTA was used. The intracellular calcium concentration at each time point was calculated from the ratio of the fluorescent intensities excited at 340 and 380 $\mathrm{nm}$ according to the equation of Grynkiewicz et al. (1985), using a dissociation constant estimated at $200 \mathrm{nM}$ for the binding of $\mathrm{Ca}^{2}+$ to the dye. For each set of cells, the maximum ratio of $340: 380 \mathrm{~nm}$ fluorescence was determined after the stimulation period by lysing the cells with $1 \%$ Triton $\mathrm{X}-100$ into low $\mathrm{K}+$ buffer containing $1.3 \mathrm{~mm} \mathrm{CaCl}$, and the minimum ratio of fluorescence was determined by subsequently adding EGTA to $80 \mathrm{~mm}$. For each value, the autofluorescence of cells which had been similarly treated except for the absence of dye was subtracted.

\section{Results}

ATP-stimulated norepinephrine release meets criteria for habituation

During habituative learning, the loss of response with repetitive stimulation is typically faster and more complete when the frequency of repctitive stimulation is increased. This effect of stimulation frequency on habituation is always detected when re-

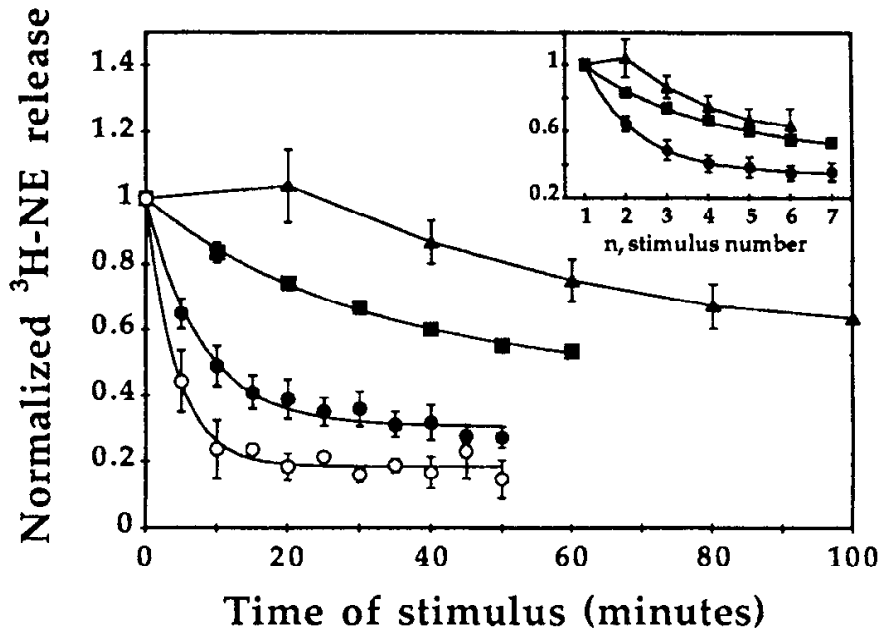

Figure 1 . Effect of stimulation frequency and intensity on habituation of the response to ATP. Neuronally differentiated PC1 2 cells grown on cytodex 3 beads were repetitively stimulated by perfusion, and the time course of ${ }^{3} \mathrm{H}-\mathrm{NE}$ release was measured. The amount of ${ }^{3} \mathrm{H}-\mathrm{NE}$ released during each $1 \mathrm{~min}$ stimulus, less the basal release, was normalized to the initial response observed in the same experiment. ATP at $300 \mu \mathrm{M}$ was applied for $1 \mathrm{~min}$ periods every $5 \mathrm{~min}(\mathbf{)}), 10 \mathrm{~min}(\boldsymbol{\square})$, or $20 \mathrm{~min}$ (A). or $30 \mu \mathrm{M}$ ATP was given for $1 \mathrm{~min}$ every $5 \mathrm{~min}(0)$. Each point represents the mean \pm SD for at least three independent measurements. Except for $300 \mu \mathrm{M}$ ATP given every $20 \mathrm{~min}$, data were fit by single exponential curves (solid lines) with constants described in the text. Inset, Responses are replotted as a function of stimulus number.

sponses to stimuli are plotted as a function of real time; in some cases this effect is also found when responses are plotted as a function of stimulus number (Thompson and Spencer, 1966). In addition, habituation is typically faster and more complete, relative to the initial response, when the stimulus intensity is decreased. PC 12 cells secrete norepinephrine (NE) in response to extracellular ATP, and the response is diminished with repetitive stimulation (Cheever and Koshland, 1992). To determine whether the loss of neurosecretory responsiveness displays these other characteristics typical of habituation, the time course of NE release was measured from $\mathrm{PC} 12$ cells repetitively stimulated at different frequencies and different stimulant concentrations.

Cells were repetitively stimulated with 1 min pulses of 300 $\mu \mathrm{M}$ ATP, a concentration that is maximally effective at evoking NE release. Stimuli were given at frequencies of one stimulus every 5,10 , or $20 \mathrm{~min}$ (Fig. 1). In each case, the neurosecretory response was diminished with repeated stimulation. Both the rate and extent of habituation were greater when repetitive stimuli were given at higher frequencies.

For 1 min stimuli given every $5 \mathrm{~min}$, the decay of the response was well fit by a single exponential curve (see Cheever and Koshland, 1992) with a rate constant for habituation of $\kappa=0.13$ $\pm 0.01 \mathrm{~min}^{-1}$, where responses were plotted as a function of time. At this stimulation frequency, the fully habituated response was $R_{H}=0.31 \pm 0.01$, where $R_{H}$ is defined as the final response level as a fraction of the initial response. When the frequency of stimulation was decreased to a 1 min stimulus given every $10 \mathrm{~min}$, the decay was still well described by a single exponential curve. The rate of habituation was decreased to $\kappa$ $=0.03 \pm 0.002 \mathrm{~min}^{-1}$ and the fully habituated response was increased to $R_{H}=0.45 \pm 0.02$, relative to the initial response. When the cells were stimulated once every $20 \mathrm{~min}$, the second 

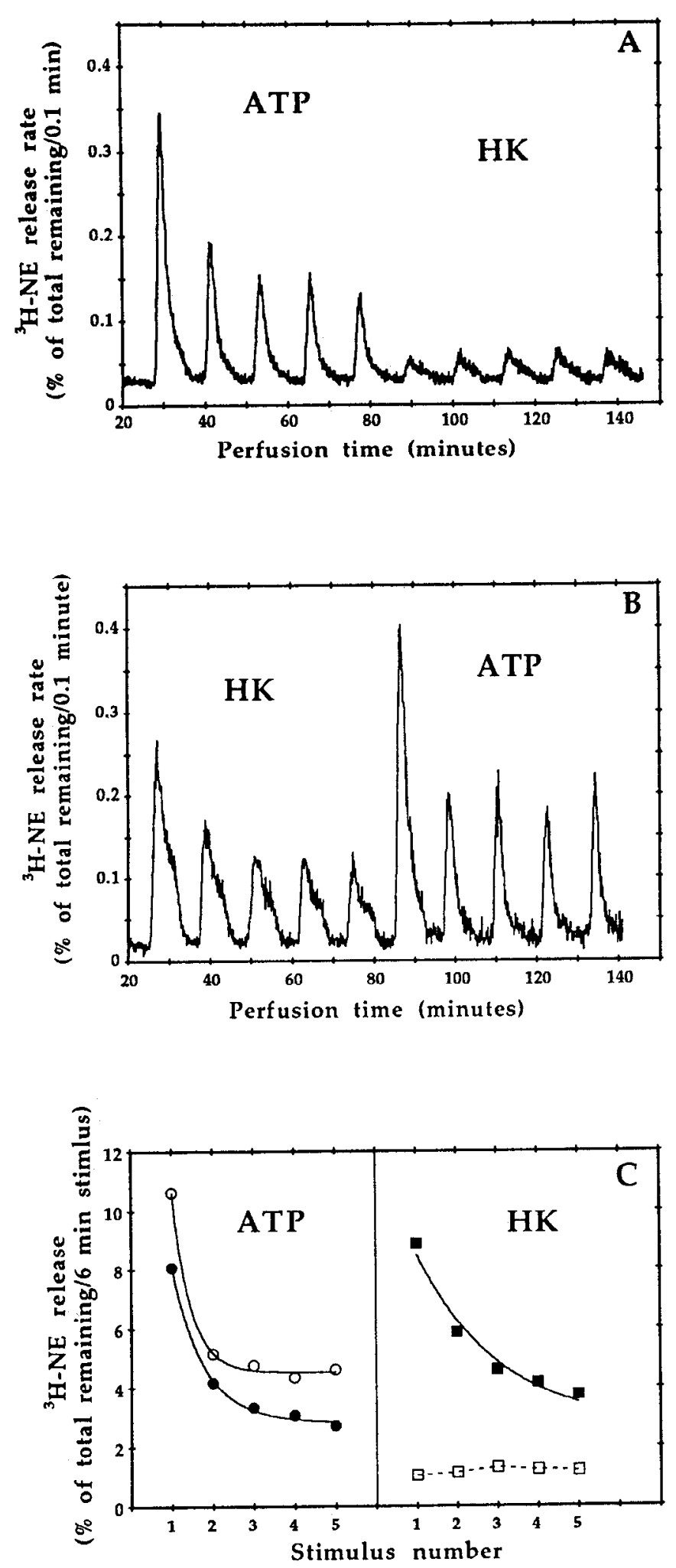

Figure 2. Generalization of habituation of the responses to ATP and high $\mathrm{K}^{+}$. The time course of ${ }^{3} \mathrm{H}-\mathrm{NE}$ release was measured from PC12 cells grown on cytodex 3 beads and repetitively stimulated by perfusion with $300 \mu \mathrm{M}$ ATP or high $\mathrm{K}^{+}(56 \mathrm{~mm} \mathrm{KCl}$ with $\mathrm{NaCl}$ reduced to maintain constant osmotic strength and all other ingredients as low $\mathrm{K}^{+}$). $A$, Cells were given a series of five $6 \mathrm{~min}$ applications of ATP separated by 6 min intervals. Six minutes after the last application of ATP, the cells were given five 6 min applications of high $\mathrm{K}^{+}$buffer, again separated by 6 min intervals. $B$, Five 6 min applications of high $\mathrm{K}^{+}$were given before five 6 min applications of ATP. Again, each interstimulus interval response may actually have been greater than the first response, possibly indicating an underlying sensitization process that is masked by extensive habituation. After the second stimulus, the response declined with an exponential time course; $\kappa$ was decreased to $0.02 \pm 0.002 \mathrm{~min}^{-1}$ and $R_{h}$ was increased to $0.54 \pm$ 0.02 .

If these data are plotted as a function of stimulus number, the rate and extent of response decrement are still dramatically decreased as the stimulation frequency is reduced from one stimulus every $5 \mathrm{~min}$ to one every $10 \mathrm{~min}$ (Fig. 1). A smaller additional decrease in habituation rate may occur when the stimulus frequency is further reduced to one every $20 \mathrm{~min}$.

When the cells were repetitively stimulated with a lower stimulus intensity, $30 \mu \mathrm{M}$ ATP, both the rate and relative extent of habituation were increased over that observed with $300 \mu \mathrm{M}$ ATP (Fig. 1). The initial response to $30 \mu \mathrm{M}$ ATP was only about $30 \%$ of the initial response observed with $300 \mu \mathrm{M}$ ATP; a 1 min application of $30 \mu \mathrm{M}$ ATP caused release of $1.7 \pm 0.4 \%$ of the total ${ }^{3} \mathrm{H}-\mathrm{NE}$ stores, in comparison with $6.5 \pm 1.5 \%$ released during a $1 \mathrm{~min}$ application of $300 \mu \mathrm{M}$ ATP. When this weaker stimulus was repetitively applied for $1 \mathrm{~min}$ every $5 \mathrm{~min}$, the rate of habituation was increased over that observed for stimulation with $300 \mu \mathrm{M}$ ATP at the same frequency to $\kappa=0.24 \pm$ $0.02 \mathrm{~min}^{-1}$ and the fully habituated response was decreased to $R_{l}=0.18 \pm 0.01$, normalized to the initial response.

Another phenomenon frequently but not always observed in behavioral studies of habituation is generalization (Thompson and Spencer, 1966). That is, habituation of the response to one stimulus, induced by repetitive presentation of that stimulus, may cause a reduction of the response to another stimulus. To test the generalization of habituation in PC 12 cells, cells were given a series of repetitive applications of one stimulant, followed by a series of repetitive applications of another stimulant

When cells were repetitively stimulated first with ATP, causing habituation of ATP-evoked NE release, the secretory response to depolarizing concentrations of potassium (HK) was also greatly reduced, relative to the response observed in naive cells (Fig. $2 A$ ). This indicates a generalization of habituation. Further repetitive stimulation with $\mathrm{HK}$ resulted in no further reduction in the response, suggesting that the response to $\mathrm{HK}$ was fully habituated after stimulation with ATP.

In contrast, if cells were repetitively stimulated with $\mathrm{HK}$ prior to stimulation with ATP, there was actually a slight increase in the amplitude of the response to ATP as compared to the response of naive cells, from $8.0 \%$ of total ${ }^{3} \mathrm{H}-\mathrm{NE}$ released during a 6 min stimulus to $10.6 \%$, indicating that the decrease in response was not generalized (Fig. $2 B$ ). Thus, there is a unilateral generalization of the decrease in NE release; $\mathrm{HK}$-evoked release is diminished following habituation of the response to ATP, but not vice versa. However, following habituation of the response to $\mathrm{HK}$, the rate of habituation to ATP was somewhat increased over that observed in cells that had not previously been stimulated. Previously unstimulated cells presented with 6 min stim-

was $6 \mathrm{~min} . C,{ }^{3} \mathrm{H}-\mathrm{NE}$ released during each stimulus, less basal, is replotted as a function of stimulus number. The decline in responses is fit with single exponential curves with constants given in the text (solid lines) for repetitive presentations of ATP given either to naive cells $(\bullet)$ or after repetitive stimulation with high $\mathrm{K}^{+}(\mathrm{O})$, and also for repetitive applications of high $\mathrm{K}^{+}$given to naive cells $(\square)$ but not to cells that have been stimulated with ATP ( $\square$ ). 


\begin{tabular}{|c|c|c|c|}
\hline $\begin{array}{l}{[\mathrm{ATP}]} \\
\mu \mathrm{M}\end{array}$ & $\begin{array}{l}\text { Decay } \\
\text { constant, } \\
\text { min }^{-1}\end{array}$ & SD & $n$ \\
\hline 10 & 1.76 & 0.20 & 3 \\
\hline 30 & 0.92 & 0.19 & 4 \\
\hline 100 & 0.58 & 0.05 & 4 \\
\hline 300 & 0.42 & 0.06 & 4 \\
\hline 1000 & 0.41 & 0.09 & 3 \\
\hline
\end{tabular}

uli of $300 \mu \mathrm{M}$ ATP separated by $6 \mathrm{~min}$ intervals habituated with a rate constant of $\kappa=0.11 \pm 0.01 \mathrm{~min}^{-1}$. Following repetitive stimulation with $\mathrm{HK}$, the rate constant for habituation was increased to $\kappa=0.19 \pm 0.03 \mathrm{~min}^{-1}$ (Fig. 2C). This suggests a different sort of generalization in which habituation of the response to one stimulus does not reduce the response to another stimulant but does cause the response to that stimulant to decrease more rapidly with repetitive stimulation (see Peeke and Petrinovich, 1984).

Thus, in PC12 cells as in animal studies, habituation of the response to one stimulant may be generalized to cause either a reduction in the response or an increased rate of habituation to another stimulant. The degree and type of generalization seen depend on the stimulants used. These interactions of the effects of different stimulants may offer clues as to the molecular mechanisms causing decreases in the response and increases in the habituation rate.

\section{$4 T P$ receptors mediating norepinephrine release}

In PC 12 cells, extracellular ATP exerts its effects by opening a receptor-operated cation channel that allows influx of calcium (Inoue, 1989), causing exocytotic release of norepinephrine. Thus, addition of ATP to the cells causes a dose-dependent increase in intracellular calcium concentrations $\left(\mathrm{Ca}_{i}\right) ; \mathrm{Ca}$ rises rapidly upon addition of ATP and then decays slowly toward the basal level (Fig. 3A). The decay of $\mathrm{Ca}_{i}$ is exponential with the rate constants described in Table 1. In the absence of extracellular calcium, no calcium influx can occur and ATP does not cause any detectable increase in $\mathrm{Ca}_{i}$ (Fig. $3 A$ ). Similarly, ATP stimulates a dose-dependent release of NE from the cells (Fig. $3 B$ ). In the absence of extracellular calcium, ATP-stimulated NE release is also undetectable. These data suggest that ATP-evoked NE release is entirely mediated by calcium influx through ATPgated channels.

Others working with a different strain of undifferentiated $\mathrm{PC} 12$ cells have suggested that a second $\mathrm{P}_{2 Y}$-type ATP receptor is also present on the surface of PC12 cells (Fasolato et al., 1990). $\mathrm{P}_{2 Y^{-}}$ type receptors (for nomenclature, see Gordon, 1986; Williams and Cusack, 1990) are expected to act via G-proteins to stimulate phospholipase $\mathrm{C}$ activity (Dubyak et al., 1988; Boyer et al., 1989; Sasakawa et al., 1989), producing inositol triphosphate and diacylglycerol and thereby causing release of calcium from intracellular stores (Berridge and Irvine, 1984) and activation of protein kinase C (cf. Nishizuka, 1992; but see Gonzalez et al., 1989). In contrast to this strain of PC1 2 cells, our PC1 2 cells

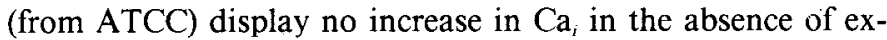
tracellular calcium (Fig. $3 A$ ), making it unlikely that $A T P$ is
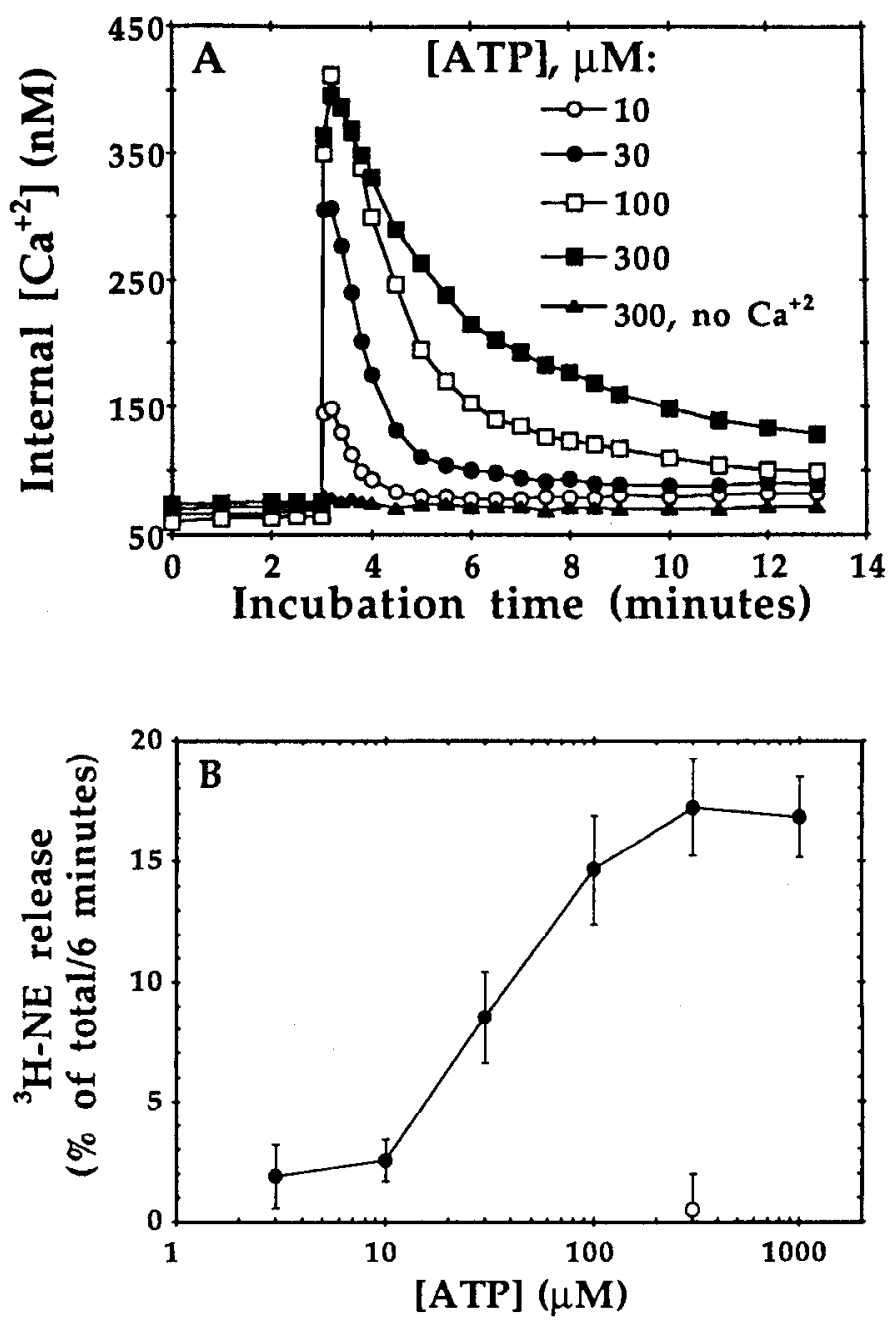

Figure 3. ${ }^{3} \mathrm{H}$-NE release and $\mathrm{Ca}_{i}$ elevations evoked by ATP. In order to quantify the relationship between ATP-evoked increases in $\mathrm{Ca}_{i}$ and $\mathrm{NE}$ release, elevations in $\mathrm{Ca}_{i}$ evoked by various concentrations of $\mathrm{ATP}$ $(A)$ and ${ }^{3} \mathrm{H}-\mathrm{NE}$ release evoked with similar treatment $(B)$ were measured $A$, Cells preloaded with fura-2 were resuspended in low $\mathrm{K}^{+}(O, \bullet, \square$, D) or calcium-free low $\mathrm{K}^{+}(\boldsymbol{\Delta})$, and intracellular calcium levels were measured. Three minutes after establishing a baseline $\mathrm{Ca}_{i}$ level, ATP was added to a concentration of $10(0), 30(\bullet), 100(\square)$, or $300(\boldsymbol{\square}, \mathbf{\Delta})$ $\mu \mathrm{M}$. $B$. Cells that had been preloaded with ${ }^{3} \mathrm{H}-\mathrm{NE}$ were incubated with the indicated concentrations of ATP in low $\mathrm{K}^{+}(\boldsymbol{)})$ or calcium-free low $\mathrm{K}^{+}(\mathrm{O})$ for $6 \mathrm{~min}$ and the percentage of ${ }^{3} \mathrm{H}-\mathrm{NE}$ that was released into the supernatant was determined. Points represent the mean \pm SD of at least six independent measurements, each made in duplicate.

acting via a $\mathrm{P}_{2 \mathrm{Y}}$ receptor to stimulate release of calcium from intracellular stores.

\section{Inactivation of the ATP-gated channel is responsible for decreased $N E$ release}

Reversible, stimulation-dependent inactivation of the machinery mediating the response to stimulation may be the simplest mechanism that could cause short-term habituation (Cheever and Koshland, 1992). For ATP-stimulated NE release, this sort of feedback inactivation could potentially occur at several points. The ATP-gated channel allowing influx of calcium could be inactivated during presentation of ATP, or some component of the secretory machinery that mediates norepinephrine release in response to cytosolic calcium might be inactivated. Alternatively, ATP might increase the activity of pumps or buffers 


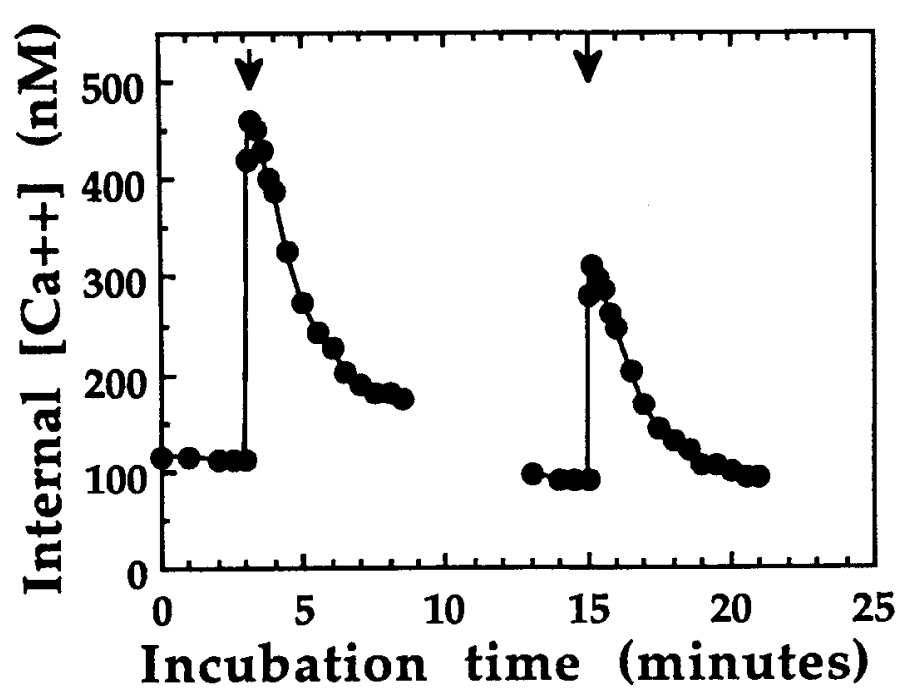

Figure 4. ATP-induced elevation of $\mathrm{Ca}_{r}$ is reduced with repetitive stimulation. Cells grown in suspension were preloaded with fura-2, and $\mathrm{Ca}$, levels were measured. ATP was added to a concentration of $300 \mu \mathrm{M}$

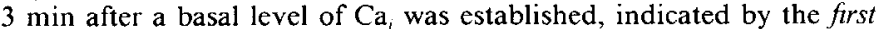
arrow. After $6 \mathrm{~min}$ in the presence of ATP, cells were washed two times with low $\mathrm{K}^{+}$during a 6 min interstimulus interval, allowing re-establishment of the basal $\mathrm{Ca}_{i}$ level. A second aliquot of ATP was then added to $300 \mu \mathrm{M}$, indicated by the second arrow.

responsible for removing and sequestering cytosolic calcium to terminate the effects of stimulation. If calcium influx were downregulated or if calcium removal were upregulated, ATP-stimulated elevations of $\mathrm{Ca}_{\text {, }}$ should be decreased with repetitive stimulation, correlating with the decrease in NE secretion. If the machinery causing release of $\mathrm{NE}$ in response to $\mathrm{Ca}_{i}$ elevation were inactivated, there should be little or no change in the levels of $\mathrm{Ca}_{j}$ induced by ATP during habituation.

To distinguish between these possibilities, the calcium-sensitive fluorescent dye fura-2 (Grynkiewicz et al., 1985) was used to measure $\mathrm{Ca}_{i}$ in cells repetitively presented with $300 \mu \mathrm{M}$ ATP (Fig. 4). The first presentation of ATP caused the $\mathrm{Ca}_{i}$ to rise from a basal level of $110 \mathrm{nM}$ to a peak level of $480 \mathrm{~nm}$ within $12 \mathrm{sec}$. After a 6 min stimulus, the ATP was washed away during a $6 \mathrm{~min}$ interstimulus interval, and $\mathrm{Ca}_{i}$ returned to the basal level. In response to a second presentation of $300 \mu \mathrm{M}$ ATP, $\mathrm{Ca}_{i}$ rose to a peak level of only $310 \mathrm{~nm}$. Thus, ATP-evoked increases in $\mathrm{Ca}_{\text {, }}$ are significantly reduced with repetitive stimulation.

To determine whether this decrease in $\mathrm{Ca}_{\text {i }}$ elevations can fully account for the observed decrease in NE release, a correlation between ATP-stimulated $\mathrm{Ca}_{i}$ levels and $\mathrm{NE}$ release occurring in naive cells was first developed. Cells were stimulated with different concentrations of ATP and changes in both $\mathrm{Ca}_{i}$ and NE release were measured (Fig. 3). For each concentration of ATP tested, the amount of ${ }^{3} \mathrm{H}-\mathrm{NE}$ release occurring during a $6 \mathrm{~min}$ stimulation, less basal, was plotted as a function of the integrated increase in calcium observed during a similar 6 min stimulation, less basal (Fig. 5). This revealed an apparently saturating relationship between increases in $\mathrm{Ca}_{i}$ and ${ }^{3} \mathrm{H}-\mathrm{NE}$ release $(0$ in Fig. 5).

ATP-evoked ${ }^{3} \mathrm{H}-\mathrm{NE}$ release and $\mathrm{Ca}_{i}$ elevations were then similarly correlated in cells that were repetitively stimulated with $300 \mu \mathrm{M}$ ATP. The relationship between $\mathrm{Ca}_{\text {, }}$ elevation and secretion in response to repetitive stimulation fell on the same line as that found in naive cells (Fig. 5, $\bigcirc$ and $\square$ ), indicating

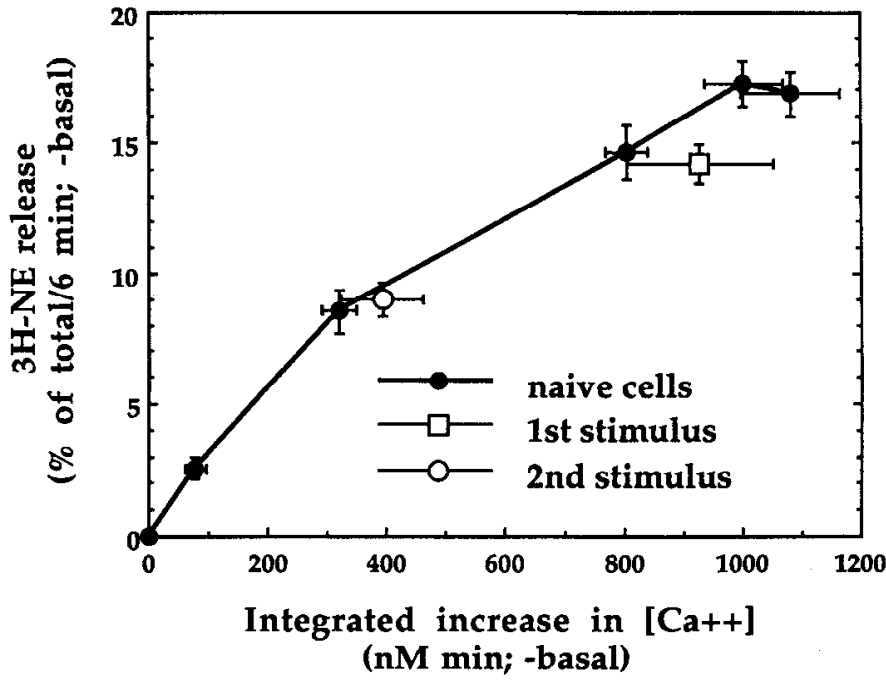

Figure 5. Relationship between ATP-stimulated increases in Ca, and $\mathrm{NE}$ release. Increases in ${ }^{3} \mathrm{H}-\mathrm{NE}$ release and $\mathrm{Ca}$, evoked by $\mathrm{ATP}$ were correlated. Observed changes in $\mathrm{Ca}$, (Fig. $3 \mathrm{~A}$ ) were integrated over a 6 min period following addition of $\Lambda$ TP; the basal level observed prior to stimulation was subtracted to give the "integrated increase in calcium." For each concentration of ATP tested, ${ }^{3} \mathrm{H}-\mathrm{NE}$ release occurring from similarly treated cells (Fig. $3 B$ ) was plotted as a function of the integrated increase in calcium (O). Data points represent the mean \pm $\mathrm{SD}$ of at least six independent measurements of ${ }^{3} \mathrm{H}-\mathrm{NE}$ release and at least three measurements of integrated increases in $\mathrm{Ca}_{i}$. The relationship between integrated calcium levels and NE secretion was similarly determined for cells repetitively stimulated with $300 \mu \mathrm{M}$ ATP. Cells, preloaded with either ${ }^{3} \mathrm{H}-\mathrm{NE}$ for release measurements or fura-2 for calcium measurements, were stimulated with $300 \mu \mathrm{M}$ ATP for 6 min (first stimulus, $\square$ ). ATP was removed by gentle centrifugation and resuspension of the cells in low $\mathrm{K}^{+}$two times during a $6 \mathrm{~min}$ interstimulus interval before a second $6 \mathrm{~min}$ application of $300 \mu \mathrm{M}$ ATP (second stimulus,

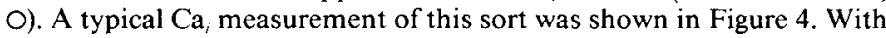
this stimulation paradigm, the response to ATP is almost completely habituated by the second repetitive stimulation; therefore, no attempt was made to correlate $\mathrm{Ca}_{i}$ and $\mathrm{NE}$ release for greater numbers of repetitive stimuli.

that the relationship between $\mathrm{Ca}_{i}$ and $\mathrm{NE}$ release is not altered with repetitive stimulation. Thus, the decrease in ATP-stimulated $\mathrm{Ca}_{i}$ elevations can fully account for the decrease in NE release. Similar results were obtained by correlating peak stimulated $\mathrm{Ca}_{i}$ levels with ${ }^{3} \mathrm{H}-\mathrm{NE}$ release, confirming that this conclusion is not an artifact of the integration methods.

The decrease in ATP-stimulated $\mathrm{Ca}_{\text {, }}$ elevations suggests that either the ATP-gated channel mediating calcium influx is downregulated or calcium removal is upregulated with repetitive stimulation. Because the relationship between $\mathrm{Ca}_{i}$ elevation and $\mathrm{NE}$ release is not changed with repetitive stimulation, it is unlikely that other mechanisms, such as inactivation of a secretory apparatus, are involved. If the activity of calcium-removing mechanisms was increased with repetitive presentation of ATP, $N E$ release in response to unregulated influxes of calcium should also be decreased. However, if only the ATP-gated cation channel were inactivated following stimulation with ATP, the response to $\mathrm{Ca}_{i}$ elevations caused by other means should be unchanged.

To test these possibilities, ${ }^{3} \mathrm{H}-\mathrm{NE}$ release occurring in response to ionomycin was measured both in previously unstimulated cells and in cells that had been treated with ATP, causing habituation of the response to ATP (Fig. 6). Ionomycin is a calcium 


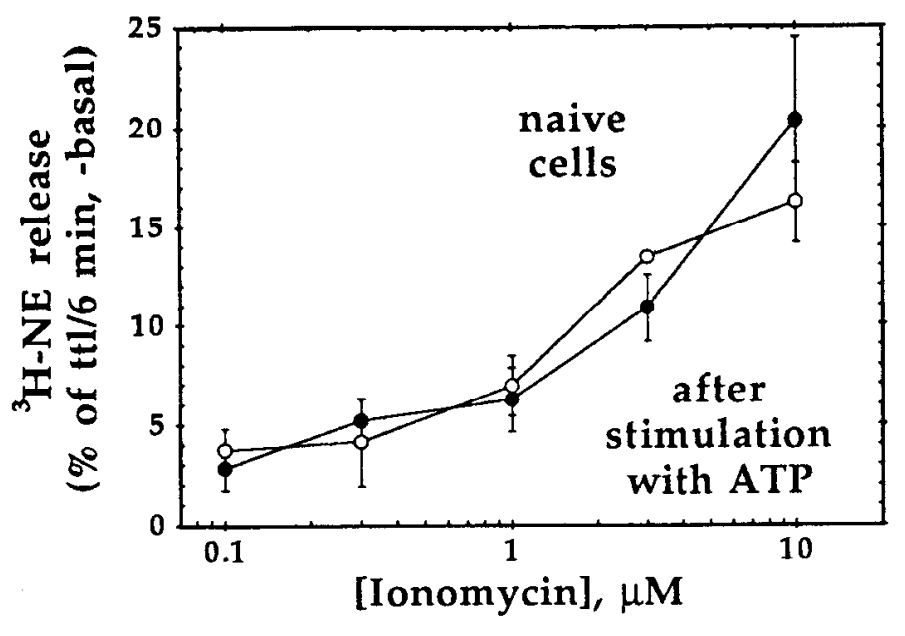

Figure 6. Release of ${ }^{3} \mathrm{H}-\mathrm{NE}$ in response to ionomycin does not change with habituation of the response to ATP. Cells grown in suspension were either habituated to ATP by stimulation with $300 \mu \mathrm{M}$ ATP for 6 $\min (\Theta)$, or were allowed to rest in low $\mathrm{K} \cdot$ buffer during this time $(O)$. ATP was removed by washing the cells two times in low $\mathrm{K}+$ buffer during a $6 \mathrm{~min}$ rest period. Cells were then stimulated with the indicated concentrations of ionomycin for $6 \mathrm{~min}$ at room temperature. The percentage of total ${ }^{3} \mathrm{H}-\mathrm{NE}$ that was released, less basal, was determined.

ionophore that allows passive diffusion of calcium across the plasma membrane, thus bypassing cell-surface cation channels and causing an unregulated elevation of $\mathrm{Ca}_{i}$ (Liu and Hermann, 1978; Bennett et al., 1979). Cells were stimulated with $300 \mu \mathrm{M}$ ATP for $6 \mathrm{~min}$; the ATP was then washed away and the cells were allowed to rest in low $\mathrm{K}^{+}$for a total interval of $6 \mathrm{~min}$ prior to stimulation with ionomycin. In these previously stimulated cells, the response to a second application of ATP would be reduced. However, the response to ionomycin was identical to that observed in naive cells (Fig. 6), indicating that the secretory response to unregulated calcium influx is unchanged.

Thus, downregulation of calcium influx through the ATPgated cation channel is likely to be responsible for the shortterm habituation of neurosecretory responses to ATP. Inactivation of both ligand- and voltage-gated ion channels in response to stimulation is common and has been reported for the ATPgated channels of PC1 2 cells (Nakazawa, 1990a,b) and other tissues (reviewed by Bean and Friel, 1990), as well as most other ion channels that have been studied. The results presented here suggest functional consequences of channel inactivation in causing habituation of neurosecretory responsiveness.

\section{Discussion}

The responsiveness of $\mathrm{PC} 12$ cells to repetitive stimulation with the neurotransmitter ATP displays characteristics typical of habituative learning as defined by Thompson and Spencer (1966). The response diminishes with repetitive stimulation, and both the rate and relative extent of response loss increase with either increasing stimulation frequency or decreasing stimulus intensity. If stimulation is withheld for a sufficient period of time following habituation, the response recovers spontaneously, and after response recovery, the rate of habituation to a second series of repetitive stimuli is increased, indicating a lasting effect of prior habituation even after response recovery (Cheever and Koshland, 1992). Habituation of the response to ATP is generalized to cause decreased neurosecretory responsiveness to depolarization. Thus, molecular reactions responsible for these properties of short- and long-term aspects of habituative learning can occur in clonal cells in the absence of interactions with other cell types.

Other characteristics frequently observed in studies of habituative learning and described by Thompson and Spencer in their classical review (1966) are "dishabituation," habituation of dishabituation, and "subzero" habituation. Dishabituation, or the ability of a strong or noxious stimulus to increase an otherwise habituated response, has been found to be mechanistically distinct from habituation in several cases (Thompson and Spencer, 1966; Marcus et al., 1988), and therefore cannot be used as a criterion for defining habituation. No attempt was made to dishabituate PC 12 cells stimulated with ATP in this study; however, the neurosecretory response of PC12 cells habituated by repetitive depolarization is known to be increased. or dishabituated, by treatment with phorbol esters (McFadden and Koshland, 1990a). Cells repetitively stimulated with ATP do not exhibit "subzero" habituation, but those stimulated with acetylcholine do (Cheever and Koshland, 1992). In distinguishing habituation in animal studies, care is taken to eliminate sensory (receptor) adaptation or muscle (effector) fatigue as causes of observed response decrements (Harris, 1943; Thompson and Spencer, 1966), in order to ensure that neuronal modulation is responsible for the behavioral changes. In these studies, neurotransmitter release was measured directly from a clonal population of neuron-like cells; therefore, any changes in the output of the system must of course be due to changes in the neuronlike cells.

The amount of informational processing and resultant modulation of responsiveness occurring in PC 12 cells seems quite remarkable. In an intact organism, similar regulation of neurotransmitter release occurring in the neurons mediating behavioral responses would be expected to produce behavioral response patterns characteristic of habituative learning. Since differentiated $\mathrm{PC} 12$ cells so closely resemble sympathetic neurons (cf. Greene and Tischler, 1976; Dichter et al., 1977), much of the habituative learning associated with sympathetic responses may be mediated at the level of the sympathetic nervous system.

Stimulation-dependent inactivation, or desensitization, of the ATP-gated channel appears to be entirely responsible for shortterm neurosecretory habituation in PC12 cells, at least at the stimulation frequencies tested. The terms "adaptation," "inactivation," and "desensitization" are often used interchangeably to indicate the decreased responsiveness of an organism, cell, or molecule occurring in the continued presence of a stimulant. "Habituation," on the other hand, is the loss of some output response to repetitive stimuli of constant intensity. Thus, adaptation or inactivation of a response element may play a role in habituation, but is not the same thing. In particular, in order for habituation to occur, a loss of responsiveness must be maintained during intervals where stimulant is absent. Furthermore, empirical observation shows that habituation is typically characterized by the parameters discussed above.

Mechanisms involving inactivation of calcium channels have been proposed to be responsible for short-term habituation of behavioral responses in several organisms (Zucker, 1971; Klein et al., 1980). Stimulation-dependent inactivation is a common feature of most ion channels responsible for neuronal excitability; this may account for the ubiquity of habituation, which has been observed in organisms ranging from protozoa to humans. However, it is likely that not every response mediated 
by ion channels that inactivate during stimulation will produce habituation. Therefore, it is useful to consider the properties of the ATP-gated channel that may allow it to produce response patterns associated with habituation.

One feature of the ATP-gated channel that allows it to cause short-term habituation is its slow recovery from stimulationinduced inactivation. Following inactivation with a brief pulse of ATP. the ATP-gated channels of PC 12 cells (Nakazawa et al., 1990b) and other tissues (Bean and Friel, 1990) require about 5 min to regain the ability to respond to stimulation. The data shown here indicate that recovery of the neurosecretory response is even slower following $1 \mathrm{~min}$ applications of ATP. This prolonged inactivation is expected to cause habituation when repetitive stimuli are presented at frequencies in the minute ${ }^{-1}$ time range. Channels that recover more rapidly would not be expected to give rise to habituation at these stimulation frequencies.

A second feature typical of habituation is a decrease in the rate and extent of habituation with decreasing stimulation frequencies. Any mechanism involving reversible, stimulation-dependent inactivation of the response machinery could theoretically account for this property (Cheever and Koshland, 1992). Therefore, it is not surprising to observe this phenomenon in PC12 cells in which reversible, stimulation-dependent inactivation of the ATP-gated channel causes reduction of the neurosecretory response to ATP.

Generalization of the loss of response may also be easily explained by this mechanism. If stimulation with ATP produces cellular conditions that cause inactivation of voltage-gated calcium channels (VGCCs), which mediate NE release in response to depolarization, then repetitive stimulation with ATP would be expected to cause inactivation of the response to depolarization, as was observed here. Most likely, inactivation of the L-type VGCCs that are present on PC12 cells requires depolarization of the cell membrane (Fox, 1981; Lux and Brown, 1984) and/or elevation of $\mathrm{Ca}_{i}$ (cf. Greenberg et al., 1985; Armstrong, 1989); stimulation with ATP causes both of these conditions (Inoue, 1989). In contrast, if depolarization does not provide the cellular conditions that cause inactivation of the ATP-gated channel, then habituation of depolarization-evoked NE release would not be generalized to ATP. Since previous depolarization does not cause inhibition of the response to ATP, the membrane depolarization and $\mathrm{Ca}_{\text {, }}$ elevation induced by treatment with potassium must not be sufficient to cause inactivation of the ATP-gated channel; possibly ATP must simultaneously be bound to the channel or the channel must be in the open state for inactivation to occur.

It is somewhat surprising that the rate and extent of habituation, relative to the initial response, are increased with decreasing stimulus intensity in PC 12 cells. In cases of ligandinduced inactivation of receptor-operated channels or other receptors, the relative rate of inactivation is typically slower with lower ligand concentrations. With repetitive stimulation, this would be expected to cause a decreased rate of habituation. However, the ATP-gated channel of PC12 cells may actually inactivate more rapidly in response to lower ligand concentrations, as suggested by the time course of changes in $\mathrm{Ca}_{i}$ in response to varying concentrations of ATP (Fig. $3 A$ ). Following application of $\mathrm{AIP}, \mathrm{Ca}_{i}$ rises to a peak level and then decays following an exponential time course; the rate constant for $\mathrm{Ca}_{\text {i }}$ decay is increased with lowcr ATP concentrations (Table 1), suggesting a faster rate of channel inactivation. This may rep- resent an unusual property of ATP-gated channels that results in an increased rate of habituation with decreased stimulus intensity. Interestingly, the rate of $\mathrm{Ca}$, decay is also somewhat increased upon repetitive application of a constant concentration of ATP. For 6 min presentations of $300 \mu \mathrm{M}$ ATP separated by a $6 \mathrm{~min}$ interstimulus interval, the mean increase in the $\mathrm{Ca}_{i}$ decay rate constant is $0.19 \pm 0.11 \mathrm{~min}{ }^{\prime}$, which is statistically significant with $p=0.02$ (naired $t$ test, $n=5$ separate experiments). This increased decay rate probably does not contribute strongly to the decreased $\mathrm{NE}$ release with repetitive stimulation, since changes in the peak level of $\mathrm{Ca}_{i}$ evoked by ATP correlate well with the changes in neurosecretion.

Thus, there seem to be several features of ATP-gated channel regulation that allow it to produce modulation of responsiveness typical of short-term habituative learning. It will be interesting to see whether other neural systems that utilize ATP as a neurotransmitter display similar habituation with repetitive stimulation. Further studies will be required to determine whether modulation of this channel also accounts for the long-term habituation of ATP-induced responses that have been observed in PC12 cells (Cheever and Koshland, 1992), or whether other reactions are involved.

\section{References}

Armstrong DL (1989) Calcium channel regulation by calcineurin, a $\mathrm{Ca}^{2+}$-activated phosphatase in mammalian brain. Trends Neurosci 12:117-122.

Bean BP, Friel DD (1990) ATP-activated channels in excitable cells. Ion Channels 2:169-203.

Bennett JP, Cockroft S, Gomperts BD (1979) Ionomycin stimulates mast cell histamine secretion by forming a lipid-soluble calcium complex. Nature 282:851-853.

Berridge MJ, Irvine RF (1984) Inositol triphosphate, a novel second messenger in cellular signal transduction. Nature 312:315-321.

Boyer JL, Downes CP, Harden TK (1989) Kinetics of activation of phospholipase $\mathrm{C}$ by $\mathrm{P}_{2,}$ purinergic receptor agonists and guanine nucleotides. J Biol Chem 264:894-890.

Castellucci VF, Kandel ER (1974) A quantal analysis of the synaptic depression underlying habituation of the gill-withdrawal reflex in Aplysia. Proc Natl Acad Sci USA 71:5004-5008.

Castellucci V, Pinsker H, Kupfermann I, Kandel ER (1970) Neuronal mechanisms of habituation and dishabituation of the gill-withdrawal reflex in Aplysia. Science 167:1745-1748.

Cheever L, Koshland DE Jr (1992) Retention of habituation in PC12 cells. Proc Natl Acad Sci USA 88:10084-10088.

Corfas Gr, Dudai Y (1989) Habituation and dishabituation of a cleaning reflex in normal and mutant Drosophila. J Neurosci 9:56-62.

Dichter MA, Tischler AS, Greene LA (1977) Nerve growth factorinduced increase in elcctrical excitability and acetylcholine sensitivity of a rat pheochromocytoma cell line. Nature 268:50 I-504.

Dubyak GR, Cowen DS, Meuller LM (1988) Activation of inositol phospholipid breakdown in HL60 cells by P2-purinergic receptors for extracellular ATP: evidence for mediation by both pertussis toxinsensitive and pertussis toxin-insensitive mechanisms. J Biol Chem 263:18108-18117.

Edwards FA, Gibb AJ, Colquhoun D (1992) ATP receptor-mediated synaptic currents in the central nervous system. Nature 359:144-147.

Farel PB, Glanzman DL, Thompson RF (1973) Habituation of a monosynaptic response in vertebrate central nervous system: lateral column-motoneuron pathway is isolated from spinal cord. $\mathbf{J}$ Neurophysiol 36:1117-1130.

Fasolato C, Pizzo P, Pozzan T (1990) Receptor-mediated calcium influx in PC12 cells. J Biol Chem 265:20351-20355.

Fox AP (1981) Voltage-dependent inactivation of a calcium channel. Proc Natl Acad Sci USA 78:953-956.

Fyffe REW, Perl ER (1984) Is ATP a central synaptic mediator for certain primary afferent fibers from mammalian skin? Proc Natl Acad Sci USA 81:6890-6893.

Gonzalez FA, Rozengurt E, Heppel LA (1989) Extracellular ATP induces the release of calcium from intracellular stores without the 
activation of protein kinase $\mathrm{C}$ in Swiss $3 \mathrm{~T} 6$ mouse fibroblasts. Proc Natl Acad Sci USA 86:4530-4534.

Gordon JL (1986) Extracellular ATP: effects, sources, and fates. Biochem J 233:309-319.

Greenberg DA, Carpenter CL, Messing RO (1985) Inactivation of $45 \mathrm{Ca}^{++}$uptake by prior depolarization of PC12 cells. Neurosci Lett 62:377-381.

Greene LA, Rein G (1977a) Release, storage and uptake of catecholamines by a clonal cell line of nerve growth factor (NGF) responsive pheochromocylomla cells. Brain Res 129:247-263.

Greene LA, Rein G (1977b) Release of $\left[{ }^{3} \mathrm{H}\right]$ norepinephrine from a clonal line of pheochromocytoma cells $(\mathrm{PC} 12)$ by nicotinic cholinergic stimulation. Brain Res 138:521-528.

Greene LA, Tischler AS (1976) Establishment of a noradrenergic clonal line of rat adrenal pheochromocytoma cells which respond to nerve growth factor. Proc Natl Acad Sci USA 73:2424-2428.

Grynkiewicz G, Poenie M, Tsien RY (1985) A new generation of $\mathrm{Ca}^{2+}$ indicators with greatly improved fluorescence properties. J Biol Chem 260:3440-3450.

Harris JD (1943) Habituatory response decrement in the intact organism. Psychol Bull 40:385-422.

Holton FA, Holton P (1954) The capillary dilator substances in dry powders of spinal roots: a possible role of adenosine triphosphate in chemical transmission from nerve endings. J Physiol (Lond) 126:124140.

Inoue K, Nakazawa K, Fujimori K, Takanaka A (1989) Extracellular adenosine 5 'triphosphate-evoked norepinephrine secretion not relating to voltage-gated $\mathrm{Ca}^{2+}$ channels in pheochromocytoma $\mathrm{PC} 12$ cells. Neurosci Lett 106:294-299.

Jahr CE, Jessel TM (1983) ATP excites a subpopulation of rat dorsal horn neurones. Nature 304:730-733.

Klein M, Shapiro E, Kandel FR (1980) Synaptic plasticity and the modulation of the $\mathrm{Ca}^{2+}$ current. J Exp Biol 89:117-157.

Kupfermann I, Castellucci V, Pinsker H, Kandel E (1970) Neuronal correlates of habituation and dishabituation of the gill-withdrawal reflex in Aplysia. Science 167:1743-1745.

Liu C, Hermann TE (1978) Characterization of ionomycin as a calcium ionophore. J Biol Chem 253:5892-5894.

Lux HD, Brown AM (1984) Single channel studies on inactivation of calcium currents. Science 225:432-434.

Marcus EA, Nolen TG, Rankin CH, Carew TJ (1988) Behavioral dissociation of dishabituation, sensitization, and inhibition in Aplysia. Science 241:210-213.

McFadden PN, Koshland DE Jr (1990a) Habituation in the single cell: diminished secretion of norepinephrine with repetitive depolarization of PC12 cells. Proc Natl Acad Sci USA 87:2031-2035.

McFadden PN, Koshland DE Jr (1990b) Parallel pathways for habituation in repetitively stimulated PC12 cells. Neuron 4:615-621.

Nakazawa K, Inoue K, Fujimori K, Takanaka A (1990a) ATP-activated single-channel currents recorded from cell-free patches of pheochromocytoma PC12 cells. Neurosci Lett 119:5-8.

Nakazawa K, Fujimori K, Takanaka A, Inoue K (1990b) An ATPactivated conductance in pheochromocytoma cells and its suppression by extracellular calcium. J Physiol (Lond) 428:257-272.

Nishizuka Y (1992) Intracellular signaling by hydrolysis of phospholipids and activation of protein kinase C. Science 258:607-614.

Peeke HVS, Petrinovich L (1984) Approaches, constructs, and terminology for the study of response change in the intact organism. In: Habituation, sensitization, and behavior (Peeke HVS, Petrinovich L, eds). New York: Academic.

Pinsker H, Kupfermann I, Castellucci V, Kandel E (1970) Habituation and dishabituation of the gill-withdrawal reflex in Aplysia. Science 167:1740-1742.

Sasakawa N, Nakaki T, Yamamoto S, Kato R (1989) Stimulation by ATP of inositol triphosphate accumulation and calcium mobilization in cultured adrenal chromaffin cells. J Neurochem 52:441-447.

Siggins GR, Groul DL, Padjen AL, Forman DS (1977) Purine and pyrimidine mononuclcotides depolarize ncurones of explanted amphibian sympathetic ganglia. Nature 270:263-265.

Thompson RF, Glanzman DL (1976) Neural and behavioral mechanisms of habituation and sensitization. In: Habituation: perspectives from child development, animal behavior, and neurophysiology (Tighe TJ, Leaton RN, eds). New York: Erlbaum.

Thompson RF, Spencer WA (1966) Habituation: a model phenomenon for the study of neuronal substrates of behavior. Psychol Rev $73: 16-43$

Williams M, Cusack NJ (1990) Neuromodulatory roles of purine nucleosides and nucleotides: their receptors and ligands. Neurotransmissions 6:1-6.

Wood DC (1988) Habituation in Stentor: a response-dependent process. J Neurosci 8:2248-2253.

Yatani A, Tsuda Y, Akaike N, Brown AM (1982) Nanomolar concentrations of extracellular ATP activate membrane $\mathrm{Ca}^{++}$channels in snail neurons. Nature 296:169-171.

Zucker RS (1971) Crayfish escape behavior and central synapses. II. Physiological mechanisms underlying behavioral habituation. J Neurophysiol 35:621-637. 